\title{
Cutaneous Melanoma Pathologic Primary Tumor TNM Finding v8
}

National Cancer Institute

\section{Source}

National Cancer Institute. Cutaneous Melanoma Pathologic Primary Tumor TNM Finding v8. NCI Thesaurus. Code C136937.

A pathologic finding about one or more characteristics of cutaneous melanoma, following the rules of the TNM AJCC v8 classification system as they pertain to staging of the primary tumor. 